\title{
EVALUATION OF BOAR SIRE BREEDING VALUE USING PROBIT METHOD**
}

\author{
$\check{C} . ~_{\text {Radović }}{ }^{*}$, M. Petrović ${ }^{2}$, B. Živković ${ }^{1}$, O. Kosovac ${ }^{1}$, \\ N. Parunović ${ }^{3}$, D. Radojković ${ }^{2}$, M. Mijatović ${ }^{2}$ \\ ${ }^{1}$ Institute for Animal Husbandry, Belgrade - Zemun, Serbia \\ ${ }^{2}$ Faculty of Agriculture, Zemun, Serbia \\ ${ }^{3}$ Institute of Meat Hygiene and Technology, Belgrade, Serbia \\ *Corresponding author, e-mail: cedomirradovic.izs@gmail.com \\ ** Original scientific paper. Research financed by the Ministry of Science of Republic of \\ Serbia, Project BTN 351008 B
}

\begin{abstract}
Objective of this paper was to evaluate breeding value of boarsires based on four traits of their offspring (average life daily gain and share of meat in carcass sides (\%) of offspring-fatteners, number of live born piglets and number of weaned piglets - boars' daughters). Investigation included sires of Swedish Landrace breed and Large White. Breeding value was evaluated on the level of population and within the breed of investigated boars. Data was processed by method of Least Squares (Harvey, 1990), and breeding values of boars evaluated using modified Probit values (Petrović et al., 1995).

Obtained results show that the highest total breeding value was established for boar No. $1(20,832)$. Its offspring were superior in three of four traits and he is at the same time the first ranked boar. Contrary to this boar, two Large White boar-sires (No. 5 and 6) had offspring with bellow average values for three of four traits. Therefore, these sires influenced improvement of only one trait in their offspring.
\end{abstract}

Key words: boar-sire, breeding value, offspring-fatteners, daughters

\section{Introduction}

Main objective in selection of boars for their further use in breeding should be their influence on improvement of economically important pig traits, i.e. production parameters in pig production. By artificial insemination, beside more rational use of boar, also greater effect in selection is achieved. Annually 2000 to 2500 doses of semen from single boar can be obtained, i.e. great number of offspring. Based on this data we 
can see that by selection and reproduction of high quality breeding boars with the highest breeding value, which in regard to their hereditary basis are adequate for to selection objective, it is possible to increase the frequency of desired genes and in this way change considerably faster the hereditary basis of the herd and population. Production of piglets is very expensive and complex process in pig production. Litter size, number of live born piglets per litter and sow annually are constant topics of research, although it is known that by selection in very short period no significant genetic progress can be achieved, primarily because of low heritability. When speaking of litter size at birth, the dependence on the genetic potential of the sow is considered as well as environment factors. However, the litter size is also under the influence of boars. It is considered that boars determine the constitution and vitality of piglets, influence number of pre-natal, peri-natal and post-natal losses, therefore it is important to choose boars with superior positive genetic potential for breeding.

Only positively tested boars can influence the improvement in pig production. Breeding heads can exhibit maximum genetic potential if they are provided with adequate nutrition, housing and microclimatic conditions.

\section{Material and methods}

Research relates to evaluation of breeding value of boar-sires of Swedish Landrace (boar-sires No. 1, 2 and 3) and Large White breed (boar-sires No. 4,5 and 6) based on traits of their offspring. In evaluation of boar-sires' breeding value four traits in their offspring were included (average life daily gain and share of meat in carcass sides (\%) of offspring-fatteners, number of live born piglets and number of weaned piglets - boars' daughters). Investigation included 410 offspring-fatteners and 182 daughters in first farrowing. Fatteners $(\mathrm{n}=212)$ were offspring of Swedish Landrace and Large White sires $(\mathrm{n}=198)$. Average number of offspring-fatteners per sire was 67,02. Of total number of offspring, 206 were males (castrated heads) and 204 females. Average number of daughters per sire was 23,81. For determination of share of meat in carcass sides, based on performed measuring, tables for meat pigs were used which are main part of the Regulation on quality of slaughtered pigs and categorization of pig meat (SL SFRJ, 1985).

Preparation of data base for statistical processing was carried out using dBase $\mathrm{III}^{+}$programme. Phenotypic variability of traits was calculated based on application of different models of the Least Square Method (LSMLMW 
and MIXMDL-Harvey, 1990).

Breeding values of boars were evaluated using modified Probit value (Petrović et al., 1995). Probit value (P) was calculated based on deviation constant of LSM values from general average $(\mu)$ under the influence of sires and absolute variation of trait (standard deviation), using the following expression:

$$
\mathrm{P}=\frac{L S M-\mu}{S D}+5=\frac{\widehat{c}_{i}}{S D}+5 \quad(\mathrm{i}=1,2,3,4) .
$$

Total breeding value represents sum of all individual breeding values.

$$
\left(\mathrm{P}_{1}+\mathrm{P}_{2}+\mathrm{P}_{3}+\mathrm{P}_{4}=\sum_{i=1}^{i=4} P i\right)
$$

Based on evaluated breeding values boars were ranked.

\section{Results and Discussion}

In table 1 evaluation of breeding values of boars based on four traits in their offspring is presented (average life daily gain, share of meat in carcass sides, number of live born piglets and number of weaned piglets) using the Probit method (P). Also based on Probit values in the same table rank of investigated boars is presented.

Table 1. Evaluation of breeding values of boars based on four traits of their offspring

\begin{tabular}{|c|c|c|c|c|c|c|c|c|}
\hline \multirow{2}{*}{ 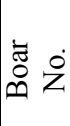 } & \multirow{2}{*}{ 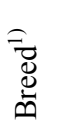 } & \multicolumn{4}{|c|}{$\mathrm{P}_{\mathrm{i}}$} & \multirow[b]{2}{*}{$\Sigma \mathrm{P}_{\mathrm{i}}$} & \multirow[b]{2}{*}{$\mathrm{P}_{i}$} & \multirow[b]{2}{*}{ 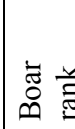 } \\
\hline & & $\mathrm{ALDG}^{2)}$ & $\mathrm{M}, \%$ & $\mathrm{NLBP}_{K}$ & $\mathrm{NWP}_{\mathrm{K}}$ & & & \\
\hline 1 & SL & 5,125 & 5,539 & 5,375 & 4,793 & 20,832 & 5,208 & 1 \\
\hline 2 & SL & 4,658 & 5,228 & 5,055 & 4,819 & 19,760 & 4,940 & 5 \\
\hline 3 & SL & 5,234 & 5,326 & 4,859 & 4,899 & 20,318 & 5,079 & 3 \\
\hline 4 & LW & 5,093 & 4,896 & 4,997 & 5,511 & 20,497 & 5,124 & 2 \\
\hline 5 & $\mathrm{LW}$ & 4,879 & 4,808 & 4,986 & 5,287 & 19,960 & 4,990 & 4 \\
\hline 6 & $\mathrm{LW}$ & 5,009 & 4,202 & 4,735 & 4,686 & 18,632 & 4,658 & 6 \\
\hline
\end{tabular}
using Probit method (P)

${ }^{1)}$ SL- Swedish Landrace, LW- Large White; ${ }^{2)}$ ALDG - average life daily gain, M- share of meat in carcass sides (\%), $\mathrm{NLBP}_{\mathrm{K}}-$ number of live born piglets and $\mathrm{NWP}_{\mathrm{K}}-$ number of weaned piglets of boar-sire daughters

If evaluated breeding values are analyzed based on ALDG of offspring it can be observed that the greatest evaluated value was determined for boar 
No. $3\left(\mathrm{P}_{\mathrm{i}}=5,234\right)$. His offspring had the highest ALDG compared to general average of all investigated fatteners. The lowest breeding value was established for boar No. $6\left(\mathrm{P}_{\mathrm{i}}=4,658\right)$. Of total of 6 boars, four boars influenced increase of ALDG in their offspring. Their offspring was above average.

The second very important trait which needs to be improved is the quality of carcass sides, i.e. meat/lean content. Evaluated breeding value based on meat yield of warm carcass sides ( $\mathrm{M} \%$ ) in offspring showed that the best evaluated boar was No. $1\left(\mathrm{P}_{\mathrm{i}}=5,539\right)$. The lowest breeding value for meat/lean content in carcass sides was observed in boar No. $6\left(\mathrm{P}_{\mathrm{i}}=4,202\right)$. Swedish Landrace boars had breeding value $P_{i} \geq 5,00$, which means that they influenced the improvement of their offspring's straits. All three Large White boars were bellow general average.

Daughters of boar No. 1 farrowed the most, and of boar No. 6 the least live born piglets in their first litter. Only two boar-sires of Swedish landrace breed influenced the increase of number of live born piglets.

Considering the size of litter at weaning, the best evaluated boar was No. $4\left(\mathrm{P}_{\mathrm{i}}=5,511\right)$, followed by boar $5\left(\mathrm{P}_{\mathrm{i}}=5,287\right)$. Both boars were large White and only these two influenced the increase of number of weaned piglets of their daughters.

The highest total breeding value was established for boar No. $1(20,832)$. His offspring were superior in three of four traits and this boar was ranked first. Contrary to him, two boar-sires of Large White breed (No. 5 and 6) had offspring who were bellow average in three of four traits. Accordingly, boars influenced improvement of only one trait in their offspring.

Based on included offspring traits for evaluation of boars' breeding values using the Probit method (Table 1) it is obvious that the boar No. 1 of Swedish landrace breed had the highest calculated Probit value and therefore ranked first of all investigated boars. Next in the rank was boar No. 4 of large White breed and the last was boar No. 6 of Large White breed with the lowest Probit value.

Evaluation of breeding values of Swedish Landrace boars based on traits of their offspring is presented in table 2. In calculations of Probit values deviation from the general average for sires breed of mean values of mentioned traits in offspring of each sire was determined.

Within the Swedish Landrace breed, the highest Probit value was established for boar No. 1 and he was also ranked first, second in the rank is boar No. 3 and the last, the worst boar No. 2. The rank remained the same as in table 1 . 
Table 2. Evaluation of breeding values of Swedish Landrace boars based on traits of their offspring

\begin{tabular}{||c|c|c|c|c|c|c|c||}
\hline \multirow{2}{*}{$\begin{array}{l}\text { Boar } \\
\text { No. }\end{array}$} & \multicolumn{4}{|c|}{$\mathrm{P}_{\mathrm{i}}$} & \multirow{2}{*}{$\Sigma \mathrm{P}_{\mathrm{i}}$} & $\overline{\mathrm{P}}_{i}$ & $\begin{array}{l}\text { Boar } \\
\text { rank }\end{array}$ \\
\cline { 2 - 8 } & $\mathrm{ALDG}^{2)}$ & $\mathrm{M}, \%$ & $\mathrm{NLBP}_{\mathrm{K}}$ & $\mathrm{NWP}_{\mathrm{K}}$ & & & 1 \\
\hline 1 & 5,119 & 5,176 & 5,278 & 4,957 & 20,53 & 5,133 & 3 \\
\hline 2 & 4,653 & 4,865 & 4,959 & 4,984 & 19,461 & 4,865 & 2 \\
\hline 3 & 5,228 & 4,964 & 4,763 & 5,064 & 20,019 & 5,005 & 2 \\
\hline
\end{tabular}

ALDG - average life daily gain, M- share of meat in carcass sides (\%), $\mathrm{NLBP}_{\mathrm{K}}-$ number of live born piglets and $\mathrm{NWP}_{\mathrm{K}}$ - number of weaned piglets of boar-sire daughters

In table 3, the evaluation of breeding values of Large White boars within the breed is presented also based on traits of their offspring like in previous tables.

Table 3. Evaluation of breeding values of Large White boars based on traits of their offspring

\begin{tabular}{||c|c|c|c|c|c|c|c||}
\hline \hline \multirow{2}{*}{$\begin{array}{c}\text { Boar } \\
\text { No. }\end{array}$} & \multicolumn{4}{|c|}{$\mathrm{P}_{\mathrm{i}}$} & \multirow{2}{*}{$\Sigma \mathrm{P}_{\mathrm{i}}$} & $\overline{\mathrm{P}}_{i}$ & $\begin{array}{c}\text { Boar } \\
\text { rank }\end{array}$ \\
\cline { 2 - 5 } & $\mathrm{ALDG}^{2)}$ & $\mathrm{M}, \%$ & $\mathrm{NLBP}_{\mathrm{K}}$ & $\mathrm{NWP}_{\mathrm{K}}$ & & & 1 \\
\hline 4 & 5,099 & 5,259 & 5,089 & 5,351 & 20,798 & 5,199 & 1 \\
\hline 5 & 4,885 & 5,171 & 5,079 & 5,128 & 20,263 & 5,066 & 2 \\
\hline 6 & 5,015 & 4,565 & 4,828 & 4,527 & 18,935 & 4,734 & 3 \\
\hline
\end{tabular}

ALDG - average life daily gain, M- share of meat in carcass sides (\%), $\mathrm{NLBP}_{\mathrm{K}}-$ number of live born piglets and $\mathrm{NWP}_{\mathrm{K}}$ - number of weaned piglets of boar-sire daughters

Based on data presented in table 3, we can see that boar No. 6 was the worst ranked and boar No. 5 had higher average Probit value by 0,332 , but lower by 0,133 compared to boar No. 4 which was ranked first within Large White breed. Large White boars kept the same rank, but average Probit values were higher than those presented in table 1 , when population averages were compared. Within its breed, boar No. 4 was superior for all four offspring traits, and within population just for two. This applies also for boar No 5. whose offspring was above sire breed average in three traits. Only in case of boar No. 6 no changes were observed, he remained worst within the large White breed.

By application of BLUP and Probit methods Petrović and Radojković (1992) evaluated breeding value of Swedish Landrace boars based on six 
traits of their daughters (life daily gain, average back fat thickness, age at farrowing, number of live born piglets, number of total born piglets and period weaning - oestrus). Results of the evaluation show that four of total nine boars influenced improvement of traits in their daughters regardless of the applied method. Collective evaluation of breeding values based on BLUP solutions was in the range from $+3,52$ to $-5,23$, and based on Probit from 4,80 to 5,20 . Breeding value of Large White boars using Probit method and based on reproductive traits of their daughters was investigated by Kosovac et al. (1995). It was established that three boars with the highest Probit values influence the improvement of production traits of offspring. The highest determined Probit value of 5,20 was established for boar No. 5 and the lowest Probit value 4,65 in boar No. 6. In evaluation of breeding values using mentioned methods authors included traits of age at first fertilization, duration of period weaning-oestrus, number of live born piglets and number of weaned piglets. In accordance with this research, Radovic et al. (2007) in evaluation of breeding value of boars based on traits of litter size at birth and weaning of sows (which they fertilized) in first three farrowings and their daughters at first farrowing, indicated that it was possible to find boars whose daughters gave birth to larger litters than the average for females of the same age. Similar results are stated by Petrovic et al. (1998 and 2000).

Using method of Least Squares (LS), Best Linear Unbiased Prediction method (BLUP) and Probit (P), Petrović et al. (1995) evaluated breeding values of boars in two herds. In the first herd, a full coincidence of breeding value evaluation between LS and BLUP methods was established (rs $=1,000)$. Strong $(\mathrm{rs}=0,533)$ correlation was determined between LS and $\mathrm{P}$ method in evaluation of breeding value of boars. In the second herd, established coincidences of breeding value evaluations between LS and P, BLUP and $\mathrm{P}$ were medium ( $\mathrm{rs}=0,465$ and $\mathrm{rs}=0,463$ ). Obtained results are in accordance with research by Kosovac et al. (1995) considering that difference in average Probit values between the best and the worst boar was 0,55 . This difference was greater $(0,55$ to 0,40$)$ than stated by Petrovic and Radojković (1992). Difference between evaluated breeding values (Table 1) of Swedish Landrace sires was lower $(5,208-4,940=0,268)$ than between LW sires $(5,124-4,658=0,466)$.

\section{Conclusion}

Considering that boars have greater influence on population traits (influence greater number of offspring and transfer positive or negative traits 
on great number of animals) it is necessary to evaluate breeding value of each boar. Results of this research indicate that it is possible to have boars whose offspring have better gain o/and higher meat yield, also that their daughters have larger litters than the average for females of the same age.

By selection and reproduction of high quality breeding boars with the highest breeding value, whose hereditary basis is adequate to the selection objective, we increase the frequency of desirable genes and in this way alter the hereditary basis of the herd, i.e. population, more rapidly. Choice of breeding boars is one of the most important links in Breeding programme in pig production since sires enable the greatest genetic progress. Poor selection of boars, from the genetical point of view as well as their health condition, can obstruct pig production causing considerable economical damage.

\title{
OCENE PRIPLODNE VREDNOSTI NERASTA- OCA METODOM PROBITA
}

\author{
Č. Radović, M. Petrović, B. Živković, O. Kosovac, N. Parunović, \\ D. Radojković, M. Mijatović
}

\section{Rezime}

Cilj ovog rada bio je da se oceni priplodna vrednost nerasta-očeva na osnovu četiri osobne potomaka (prosečan životni dnevni prirast i udeo mesa u polutkama (\%) potomaka-tovljenika, broj živorođene prasadi i broj zalučene prasadi kćeri nerasta). Ispitivanjem su obuhvaćeni očevi rase švedski landras i veliki jorkšir. Priplodna vrednost je ocenjena na nivou populacije i unutar rase ispitivanih nerasta. Podaci su obrađeni metodom najmanjih kvadrata (Harvey, 1990), a priplodne vrednosti nerasta ocenjene su primenom modifikovane vrednosti probita (Petrović et al., 1995).

Dobijeni rezultati pokazuju da je najveću ukupnu priplodnu vrednost imao je nerast br. $1(20,832)$. Njegovi potomci su bili nadmoćniji u tri od četiri osobine. On je i prvo rangirani nerast. Suprotno od njega, dva nerastaoca rase veliki jorkšir (br. 5 i 6) su imali potomke koji su za tri od četiri osobine bili ispod proseka. Prema tome ovi očevi su uticali na poboljšanje samo jedne osobine potomaka.

Ključne reči: nerast-otac, priplodna vrednost, potomci-tovljenici, kćeri 


\section{References}

HARVEY R.W. (1990): User's guide for LSMLMW and MIXMDL. Ver. PC-2, 1-91.

KOSOVAC O., PETROVIĆ M., JOKIĆ Ž. (1995): Uticaj nerastova velikog jorkšira na plodnost kćeri čiste rase i F1 generacije. Veterinarski glasnik, 49, 11-12, 679-683.

PETROVIĆ M., RADOJKOVIĆ D. (1992): Ocena priplodne vrednosti nerastova primenom mešovitog modela. Biotehnologija u stočarstvu, 8, 5-6, 209-214.

PETROVIĆ M., OLGA K., RADOJKOVIĆ D. (1995): Mogućnosti ocene priplodne vrednosti nerastova upotrebom različitih metoda. Biotehnologija u stočarstvu, 11, 3-6, 135-140.

PETROVIĆ M., VUKOVIĆ V., RADOJKOVIĆ D., BELIČOVSKI S. (1998): Estimation of breeding value of boars based on fertility of their daughters. Macedonian Agricultural Review, 45, 1-2, 91-94.

PETROVIĆ M., VUKOVIĆ V., TRIVUNOVIĆ S., RADOJKOVIĆ D. (2000): Ocena fenotipske i genetske varijabilnosti veličine legla i priplodne vrednosti nerastova. Biotehnologija u stočarstvu, 17, 5-6, 17-24.

RADOVIĆ Č., PETROVIĆ M., ŽIVKOVIĆ B., KOSOVAC O., FABJAN M., RADOJKOVIĆ D., MIJATOVIĆ M. (2007): Estimation of boar fertility based on litter size of sows and daughters. Journal of Mountain Agriculture on the Balkans, 10, 2, 213-229. 